Empire Rheumatism Council confirmed the belief among rheumatologists throughout the world that in active rheumatoid disease chrysotherapy is beneficial. The answer to the second question is not so easy to answer. But the benefit of gold treatment to so many sufferers from this remorseless and progressively crippling disease is such that many rheumatologists would advise it. After reviewing results of gold therapy by different investigators since 1929 , covering 8,198 cases with $60.7 \%$ successful results, $H$. Witzgall ${ }^{18}$ recommended its wider use under close supervision as an early treatment of rheumatoid arthritis. All forms of treatment have their dangers-surgery, corticosteroids, phenylbutazone, even aspirin. Any drug that does good can also do harm, and though rheumatoid arthritis is not itself a killing disease it appears to hasten death. E. G. L. Bywaters and his colleagues, ${ }^{19}$ in a follow-up study of 250 patients with rheumatoid arthritis, reported 131 deaths. Seventy-six of these patients died within a ten-year period, their death being due not so much to specific complications as to all the usual causes at an earlier age. The subject was recently reviewed in the B.M.F. ${ }^{20}$

What can be done to lessen the dangers of chrysotherapy? Patients with active, early disease and with high erythrocyte sedimentation rates, much inflammatory change, and the minimum of irreversible damage are usually thought to respond best. It is doubtful if an initial marrow biopsy would help in rejecting unsuitable patients. Despite their failing to provide a full safeguard full blood counts, with platelet counts, should be done every four to six weeks, and the patient should be warned to report sore throats, fevers, and unexplained, odd, ill feelings, being specially asked about them at each attendance before the injection is given. Urine testing and the examination of the skin and buccal mucosa for reactions are mandatory.

The only preparation generally available in Great Britain, sodium aurothiomalate, is today very seldom given in larger dosage than $50 \mathrm{mg}$ weekly by intramuscular injection, and the dosage is often less than this. Caution should be taken to reduce the dosage as the patient improves, joint inflammation diminishes, and the sedimentation rate falls. E. J. and $\mathbf{M}$. Denman $^{21}$ have used lymphocyte transformation in vitro as a test of hypersensitivity in an attempt to predict sensitivity reactions before overt toxic effects occur, but so far no certain, practical, simple way of predicting them has been found. J. D. Jessop ${ }^{22}$ recently reported blood dyscrasias in two patients with average therapeutic levels of gold, and $\mathbf{R}$. $\mathbf{H}$. Freyberg and his colleagues ${ }^{23}$ as long ago as 1941 wrote that they could not find any relationship between serum gold levels, response to therapy, and the development of toxic reactions. Constant vigilance, an awareness of the risks, and above all repeated blood counts with careful and accurate platelet counts are essential. Even so, sudden haematological crises may occur which dimercaprol, penicillamine, corticosteroids, and antibiotics may fail to control.

\footnotetext{
1 Møllgaard, H., et al., Chemotherapy of Tuberculosis, København, Nordisk Forlag, 1924

2 Lande, K., Münchener medizinische Wochenschrift, 1927, 74, 1132.

3 Pick, E., Wiener klinische Wochenschrift, 1927, 40, 1175.

- Forestier, J., Bulletin de la Société Médicale des Hópitaux de Paris, 1929, $53,323$.

5 Forestier, J., Lancet, 1932, 1, 441

6 Forestier, J., Lancet, 1934, 2, 646.

7 Hartfall, S. J., Garland, H. G., and Goldie, W., Lancet, 1937, 784, 838 Ellman, P., Lawrence, J. S., and Thorold, G. P., British Medical fournal, $1940,2,314$.

- Fraser, T. N., Annals of the Rheumatic Diseases, 1945, 4, 71.

10 Waine, H., Baker, F., and Mettier, S. R., California Medicine, 1947, 66, 295.

11 Adams, C. H., and Cecil, R. L., Annals of Internal Medicine, 1950, 33, 163.
}

12 Lockie, L. M., Norcross, B. M., and Riordan, D. J., Fournal of the American Medical Association, 1948, 167, 1204.

s Merliss, R. R., Axelrod, B., Fineberg, J., and Melnik, M., Annals of Internal Medicine, 1951, 35, 352.

14 Peebles Brown, R. A., and Currie, J. P., British Medical fournal, 1953, 1,

15 Empire Rheumatism Council, Annals of the Rheumatic Diseases, 1960, $19,95$.

16 Empire Rheumatism Council, Annals of the Rheumatic Diseases, 1961, $20,315$.

17 Handlova, D., Unitr̄ní Lékarství, 1968, 14, 115.

18 Witzgall, H., Therapiewoche, 1968, 18, 42.

Bywaters, E. G. L., Curwen, M., Dresner, E., and Dixon, A. St.J., Annals of the Rheumatic Diseases, 1961, 20, 198.

20 Hart, F. D., British Medical fournal, 1970, $2,747$.

21 Denman, E. J., and Denman, A. M., Annals of the Rheumatic Diseases, $1968,27,582$.

22 Jessop, J. D., British Medical fournal, 1971, 1, 49.

23 Freyberg, R. H., Block, W. D., and Levey, S., fournal of Clinical Investigation, 1940, 20, 401 .

\section{Septic Gonococcal Dermatitis}

Since 1937, as the result of the introduction of the systemic treatment of gonorrhoea, many complications that often used to be described are now rarely seen. Evidence that a gonococcaemia with associated skin lesions still occurs was contained in a report from the United States ${ }^{1}$ in 1963, and since then reports have appeared of a similar condition from other countries, including the United Kingdom. ${ }^{2}$ Now in this week's issue of the B.M.F. a well-documented article by Drs. J. Barr and D. Danielsson (page 482) describes 23 patients (19 women and 4 men) seen in the Orebro district of Sweden since 1968 with what they term septic gonococcal dermatitis. This condition was diagnosed from among 914 men and 831 women with gonorrhoea, an incidence of $0.4 \%$ and $2 \cdot 3 \%$ respectively.

The main features of the condition were fever associated with embolic skin lesions and minor affections of joints. The duration of symptoms was usually short. Eighteen patients had bouts of pyrexia, and all except two had symptoms in one or more joints, with pain alone or combined with swelling, redness, and non-pitting oedema of periarticular tissues. Joint effusions were slight or absent. The skin lesions were not usually a presenting feature but when found by careful examination were the most important diagnostic sign. The lesions varied from discrete maculopapules and vesiculopustules $1-5 \mathrm{~mm}$ in diameter to haemorrhagic papules and vesiculopustules 4-20 $\mathrm{mm}$ in diameter, often surrounded by an erythematous zone. Two patients presented with painful subcutaneous nodules rather like those of erythema nodosum. All lesions were irregularly distributed, with a partiality for the extremities and the periarticular regions. The genitourinary symptoms and signs in both sexes were minimal. The condition has to be differentiated from chronic meningococcal septicaemia.

Neisseria gonorrhoeae was isolated from all the patients except one-from the urethra of three men, and from the genitourinary tract of 17 women, and from the blood of one man and two women. Culture from the skin lesions was negative in eight patients. However, with immunofluorescent techniques $N$. gonorrhoeae was detected in 14 of 16 skin specimens examined. The complement fixation blood tests showed antibodies in 17 of 21 patients examined in this way, but these antibodies were not present in the acute phase.

All patients responded to a 12-day course of penicillin with 4.5 megaunits daily given over the first two days. In some patients there was a tendency for spontaneous remission of symptoms before treatment was begun. 
The authors did not discuss the reason why gonococcal dermatitis was more common in women than in men. It may be because gonococcaemia is apt to follow damage to the genitourinary tract after abortion, childbirth, or surgical procedures such as dilatation and curettage. But probably other factors are involved, and efforts should be made to elucidate them so that septicaemia can be prevented.

Taken together the published reports show this complication of gonorrhoea to follow in about $2 \%$ of cases. If this figure is applied to cases of gonorrhoea at present reporting at the clinics in the United Kingdom, at least 900 cases of septic dermatitis may be occurring per year. As with the Swedish experience, cases may be labelled as "benign bacteriaemia," "allergic rash," "virus intection," or "benign rheumatic fever." Few patients will present initially to the venereologist, but will be seen by general practitioners or in hospital by physicians, dermatologists, or orthopaedic surgeons. In most cases penicillin or some other antibiotic will probably be given as empirical treatment without the correct diagnosis being reached. It is therefore appropriate that the attention of all doctors in general and specialist practice should be drawn to this metastatic complication of gonorrhoea.

Abu-Nassar, H., Hill, N., Fred, H. L., and Yow, E. M., Archives of Internal Medicine, 1963, 112, 731

Wolf, C. B., Goodman, H. V., and Vahrman, J., British Medical Journal, $1970,2,271$.

\section{Glibenclamide for Diabetes}

The hypoglycaemic properties of the sulphonamide $p$-aminobenzene-sulfamido-isopropyl-thiodiazole were first reported in 1944 by $\mathrm{A}$. Loubatières ${ }^{1}$ after the unexplained death of three patients suffering from typhoid fever who were treated with the drug. Other patients treated with it had convulsions, and still others had a fall in blood sugar. Typhoid fever had been considered to predispose to hypoglycaemia, but Loubatières showed that the drug was hypoglycaemic in the normal, fasting dog.

In 1954 the sulphonamide derivative 1-butyl-3-sulphonylurea (carbutamide) was under clinical test for antibacterial activity and found to cause neurological disturbances. During a study of these side effects the drug was observed to cause hypoglycaemia. ${ }^{2}$ Carbutamide became the first of a number of sulphonylurea derivatives to be used in the treatment of diabetes. Though no longer used in Britain, its successors tolbutamide, chlorpropamide, tolazamide, and acetohexamide have been and are widely prescribed and have largely replaced insulin in the treatment of those maturity-onset diabetics not controlled by dietary restriction alone. A relative newcomer to this class of drugs is glibenclamide. ${ }^{34}$

A striking feature of glibenclamide is its potency. Most of the direct comparisons have been made with tolbutamide, and the relative potency of the two drugs varies somewhat, depending on the method of testing. The difference can best be seen in the maximum daily dose usual in treating diabetics, which is $20 \mathrm{mg}$ for glibenclamide and $3 \mathrm{~g}$ for tolbutamide. Given by mouth to healthy volunteers, about $45 \%$ of the drug was absorbed. The maximum concentration in the blood was 2-4 hours after administration, and the biological half-life was five hours. ${ }^{5}$ Virtually all the drug was metabolized to two predominant, hydroxylated derivatives, which were excreted via urine and bile. The metabolic effects of glibenclamide resemble those of the other sulphonylureas. Both in vivo and in vitro the release of insulin from the pancreatic beta cells is increased, and a fall in blood glucose depends on the presence of some functioning pancreatic tissue. ${ }^{6}$ Glibenclamide differs from tolbutamide in its qualitative as well as quantitative effects on insulin release, but these differences may be due to distribution rather than mode of action of the drugs. ${ }^{7}$

In clinical use a single daily dose of glibenclamide is sufficient, and there is usually no advantage in increasing the frequency of administration. As $2.5 \mathrm{mg}$ (half a tablet) has caused hypoglycaemia in some patients ${ }^{8}$ caution is necessary in instituting therapy with glibenclamide. The range of dosage is from 2.5 to $20 \mathrm{mg} /$ day, with most patients requiring 5-10 mg. Untoward effects reported so far have been mainly attacks of hypoglycaemia, attributable to potency rather than toxicity. Because of this potent hypoglycaemic effect it has been suggested that the drug should be used only in patients who have failed to respond to treatment with diet and one of the other sulphonylureas, ${ }^{9}$ and this advice appears to be wise. In relation to hypoglycaemia it should also be remembered that, like the other sulphonylureas, the effects of glibenclamide are probably potentiated by certain other drugs, including sulphaphenazole, phenylbutazone, and dicoumarol. For those patients under treatment with chlorpropamide who experience facial flushing, headache, and palpitations after even small quantities of alcohol glibenclamide comes as a potential relief, for not only is intolerance to alcohol rare among patients on glibenclamide but cases have been reported of the intolerance disappearing on changing to that drug from chlorpropamide. ${ }^{1011}$

Glibenclamide thus appears to be a useful addition to the range of oral hypoglycaemic sulphonylureas, but because of its potency (and its expense) it is probably best used as a second or third line of attack in patients whose blood-glucose control is inadequate with other therapy.

No discussion of the use of oral hypoglycaemic drugs is now complete without reference to the study of the American University Group Diabetes Programme, now published ${ }^{12}$ and the subject of previous comment in these columns. ${ }^{13}$ On the results of the long-term use of tolbutamide reported in this study the U.S. Food and Drug Administration issued a warning about oral hypoglycaemic drugs and recommended much more stringent limitations on their use than were applied previously. Opinion in Britain has not gone all the way with this condemnation. But it may be accepted that the long-term effects of all forms of treatment-dietary, oral drugs, and insulin - in diabetes of maturity onset require further evaluation.

Loubatières, A., Comptes Rendus des Sèances de la Societè de Biologie, $1944,138,766$

2 Franke, H., and Fuchs, J., Deutsche medizinische Wochenschrift, 1955, 80,1449 .

${ }_{3} \mathrm{HB} 419$, A New Oral Antidiabetic Drug. Hormone and Metabolic Research, Supplement Vol. 1, 1969. Ed. R. Levine and E. F. Pfeiffer.

+ Postgraduate Medical fournal, 1970, December Supplement, 46.

Christ, O. E., Heptner, W., and Rupp, W., in Hormone and Metabolic Research, Supplement, Vol. 1, 1969, p. 5i. Ed. R. Levine and E. F. Pfeiffer.

- Loubatières, A., et al., in Hormone and Metabolic Research, Supplement, Vol. 1, 1969, p. 18.

Raptis, S., et al., in Hormone and Metabolic Research, Supplement, Vol. 1, 1969 , p. 65.

Davidson, M., Lewis, A. A. G., and de Mowbray, R. R., Postgraduati Medical fournal, 1970, 46, December Supplement, p. 70.

Beyer, J., and Schoffling, K., Postgraduate Medical fournal, 1970, 46, December Supplement, p. 78 .

10 Jackson, W. P. U., and Vinik, A. I., South African Medical Yournal. 1969, 43, 1002 .

' O'Sullivan, D. J., and Cashman, W. F., British Medical Fournal. 1970, $2,572$.

12 Diabetes, 1970, 19, Supplement No. 2.

13 British Medical fournal, 1970, 4, 444. 